\title{
MELATIHKAN KEMAMPUAN BERPIKIR KREATIF DAN PEMAHAMAN KONSEP DENGAN PEMBELAJARAN BERBASIS INKUIRI TERBIMBING PADA MATERI INTERAKSI MAKHLUK HIDUP DENGAN LINGKUNGAN
}

\author{
Eddy Mufiannoor ${ }^{1)}$, M. Thamrin Hidayat ${ }^{2)}$, Soetjipto ${ }^{3)}$ \\ 1)Mahasiswa Program Studi Pendidikan Dasar, Program Pascasarjana Universitas Negeri Surabaya \\ ${ }^{2), 3)}$ Dosen Pascasarjana Prodi Pendidikan Sains Univesrtitas Negeri Surabaya \\ email: eddymoefie@gmail.com
}

\begin{abstract}
Teaching and learning process of natural science subjects includes aspects of: knowledge, skill, and thinking competence. Teachers did not implement the teaching activity which emphasize on thinking and conceptual understanding process because of limited time to make teaching and learning set which can train students' creative thinking and conceptual understanding competence. This research aimed to produce teaching and learning set of natural science subject that is valid, practice, and effective to train creative thinking and conceptual understanding competence of junior high school students. This research was conducted to implement the teaching and learning set based on guided Inquiry. The target of this research was teaching and learning set. The design of this research is research and development research using Thiagarajan's 4D model with one group pre-test post-test design. The data analysis technique used descriptive quantitative. Learning-based guided Inquiry was successful to train creative thinking and conceptual understanding competence. The result of creative thinking showed that the average score of pre-test was 42,61 and 83,19 of post-test with 0,70 of N-Gain, categorized as high level. The result of conceptual understanding (knowledge) showed that the average score of pre-test was 41,30 and 86,30 of post-test with 0,77 of NGain, categorized as high level. Based on the research result, it can be concluded that teaching and learning set of natural science subjects based guided Inquiry has been developed and it is valid, practice, and effective train students' creative thinking and conceptual understanding competence.
\end{abstract}

Key Words: Creative Thinking Competence, Conceptual Understanding, Guided Inquiry.

Abstrak: Proses pembelajaran IPA meliputi aspek sikap, pengetahuan, keterampilan, dan kemampuan berpikir. Guru belum melaksanakan pembelajaran yang menekankan pada proses berpikir dan pemahaman konsep karena keterbatasan waktu dalam menyusun perangkat pembelajaran yang dapat melatihkan kemampuan berpikir kreatif dan pemahaman konsep. Penelitian ini bertujuan untuk menghasilkan perangkat pembelajaran IPA yang valid, praktis, dan efektif untuk melatihkan kemampuan berpikir kreatif dan pemahaman konsep pada siswa SMP. Pembelajaran ini dilakukan dengan cara menerapkan perangkat pembelajaran berbasis inkuiri terbimbing. Sasaran penelitian adalah perangkat pembelajaran. Penelitian ini merupakan penelitian pengembangan dengan model 4D dari Thiagarajan dan desain ujicoba penelitian menggunakan one group pre-test post-test. Teknik analisis data menggunakan deskriptif kuantitatif. Pembelajaran berbasis inkuiri terbimbing berhasil melatihkan kemampuan berpikir kreatif dan pemahaman konsep. Hasil belajar tes berpikir kreatif, rata-rata persentase pretest sebesar 42,61 dan posttest 83,19 dengan rata-rata N-Gain sebesar 0,70 dengan kategori tinggi. Hasil belajar pemahaman konsep siswa (aspek pengetahuan), rata-rata pretest sebesar 41,30 dan posttest 86,30 dengan rata-rata $\mathrm{N}$-Gain sebesar 0,77 dengan kategori tinggi. Berdasarkan hasil analisis data dan diskusi hasil serta temuan-temuan, dapat disimpulkan bahwa perangkat pembelajaran IPA berbasis inkuri terbimbing yang telah dikembangkan valid, praktis, dan efektif untuk melatihkan kemampuan berpikir kreatif dan pemahaman konsep siswa.

Kata Kunci: Kemampuan Berpikir Kreatif, Pemahaman Konsep, Inkuiri Terbimbing.

\section{PENDAhULUAN}

Dunia kerja dan masyarakat saat ini membutuhkan orang-orang yang kompetitif atau memiliki daya saing, dan untuk memenuhi hal tersebut pendidikan berperan penting menyiapkan peserta didik agar memiliki kemampuan tersebut untuk menghadapi masa kini dan masa yang akan datang. Penyempurnaan kurikulum dilakukan untuk menyiapkan kualitas sumberdaya manusia agar sesuai dengan perkembangan ilmu pengetahuan dan tuntutan masyarakat yang semakin maju. Kurikulum 2013 dirancang dengan tujuan untuk menciptakan insan Indonesia yang beriman, produktif, kreatif, dan inovatif serta mampu memberikan kontribusi pada kehidupan bermasyarakat, berbangsa, bernegara, dan peradaban dunia (Dokumen Kurikulum 2013).

Guru melaksanakan proses pembelajaran umumnya hanya terfokus pada bagaimana suatu materi tuntas disampaikan kepada siswanya tanpa memikirkan bagaimana cara siswa belajar dan mengembangkan 
kemampuan-kemampuan yang dimilikinya. Proses pembelajaran kurang memberdayakan kemampuan berpikir siswa dan mengarahkan siswa untuk bekerja secara ilmiah. Hal ini juga didukung penemuan Rofi'udin dalam Arnyana (2007) bahwa terjadi keluhan tentang rendahnya kemampuan berpikir kritis-kreatif yang dimiliki oleh lulusan pendidikan dasar sampai perguruan tinggi. Pembelajaran yang menekankan pada kemampuan berpikir belum ditangani dengan baik dan hal ini tentunya tidak sejalan dengan UU No. 20 Tahun 2003 tentang Sistem Pendidikan Nasional pada Pasal 3, yang menyebutkan bahwa Pendidikan Nasional bertujuan untuk berkembangnya potensi peserta didik agar menjadi manusia yang beriman dan bertakwa kepada Tuhan Yang Maha Esa, berakhlak mulia, sehat, berilmu, cakap, kreatif, mandiri, dan menjadi warga negara yang demokratis serta bertanggung jawab.

Hakekat Kurikulum 2013 menjelaskan bahwa proses pembelajaran IPA meliputi pengetahuan, keterampilan, dan sikap serta kemampuan berpikir melalui interaksi langsung dengan sumber belajar (Kemendikbud, 2014). Pemahaman konsep dalam proses belajar mengajar sangat mempengaruhi sikap, keputusan dan cara menyelesaikan masalah. Menurut Ibrahim (2012), pemahaman konsep amat penting bagi setiap orang, menguasai konsep dengan baik, luas dan mendalam, memungkinkan seseorang dapat menerapkan penguasaannya dalam berbagai keperluan. Penguasaan konsep merupakan kemampuan yang memungkinkan seseorang dapat berbuat sesuatu. Hal ini dapat diartikan bahwa tanpa menguasai konsep tertentu, seseorang tidak dapat berbuat banyak dan mungkin kelangsungan hidupnya akan terganggu. Salah satu kemampuan proses mental yang diperlukan dalam memahami konsep adalah kemampuan berpikir.

Liliasari (2000) membedakan kemampuan berpikir dasar dan kemampuan berpikir tingkat tinggi. Berpikir kreatif adalah aktivitas mental untuk mengembangkan atau menemukan ide-ide asli (orisinil), estetis, konstruktif yang berhubungan dengan pandangan konsep, dan menekankan pada aspek berpikir intuitif dan rasional (Arnyana, 2006). Krulik and Rudnick (dalam Arnyana, 2006) mengemukakan bahwa orang yang memiliki kecakapan berpikir kreatif atau sering juga disebut berpikir divergen memiliki daya kreativitas yang tinggi dan bermanfaat bagi banyak orang. Berdasarkan pernyataan tersebut, maka kecakapan berpikir kreatif ini sangat penting diajarkan di sekolah.

Pembelajaran IPA diharapkan dapat menjadi sarana dalam mengembangkan keterampilan berpikir kreatif untuk memperoleh pemahaman yang benar terhadap konsep-konsep materi yang dipelajari. Tujuan pembelajaran IPA pada jenjang SMP dalam Permendikbud No. 58 Tahun 2014.
Berdasarkan hasil wawancara dengan guru IPA SMP Negeri 1 Batumandi Kalimantan Selatan, ditemukan penyebab belum terlaksananya secara maksimal kemampuan berpikir kreatif dan pemahaman konsep siswa, diantaranya keterbatasan waktu guru untuk mengembangkan perangkat pembelajaran IPA yang dapat melatihkan kemampuan berpikir kreatif dan pemahaman konsep dalam pembelajaran IPA. Guru juga mengalami kesulitan dalam menangani siswa berkemampuan rendah agar dapat lebih aktif dalam pembelajaran dan termotivasi dalam pembelajaran. Temuan lain dalam angket yang disebarkan ke beberapa siswa, bahwa siswa kurang paham dengan beberapa konsep IPA serta belum berani mengusulkan ide atau gagasan pada saat pembelajaran. Peran guru dalam proses pembelajaran sangat penting. Menurut UndangUndang No. 14 Tahun 2005 tentang Guru dan Dosen menegaskan bahwa guru harus memiliki 4 (empat) kompetensi yaitu pedagogik, profesional, kepribadian, dan sosial (Dokumen Undang-Undang RI., 2005).

Salah satu pembelajaran yang menekankan keterlibatan siswa dalam mengembangkan keterampilan berpikir dan berusaha menemukan konsep dalam proses pembelajaran adalah inkuiri. Strategi pembelajaran ini juga sejalan dengan Kurikulum 2013 yang menekankan pada dimensi pedagogik modern dalam pembelajaran, yaitu menggunakan pendekatan ilmiah (scientific approach). Metode yang dipandang sejalan dengan prinsip pendekatan saintifik/ ilmiah adalah Problem Based Learning (PBL), Project Based Learning (PJBL), dan Inquiry Learning (Kemendikbud, 2014). Peneliti menggunakan pembelajaran berbasis inkuiri terbimbing untuk melatihkan kemampuan berpikir kreatif dan pemahaman konsep. Materi pembelajaran dalam penelitian ini yaitu interaksi makhluk hidup dengan lingkungan. Konsep-konsep yang ada dalam materi tersebut dapat ditemukan oleh siswa di lingkungan sekitar mereka, sehingga materi ini dapat diajarkan dengan pembelajaran berbasis inkuiri terbimbing. Pembelajaran berbasis inkuiri terbimbing memberikan kesempatan yang luas kepada siswa untuk menemukan sendiri konsep-konsep yang ada dalam materi interaksi makhluk hidup dengan lingkungan sehingga siswa dapat mengembangkan diri untuk berpikir kreatif. Menurut Untari (2013), metode-metode tersebut mengajarkan kepada peserta didik untuk mengenal masalah, merumuskan masalah, mencari solusi, menguji jawaban sementara dengan melakukan penyelidikan (menemukan fakta-fakta melalui penginderaan), dan pada akhirnya menarik kesimpulan dan menyajikan secara lisan maupun tertulis. Pelaksanaan proses pembelajaran di kelas diperlukan perangkat pembelajaran meliputi silabus, RPP, LKS, Buku Ajar Siswa, serta Lembar Penilaian yang dapat mendukung proses pembelajaran tersebut. 
Berdasarkan uraian latar belakang masalah di atas, maka untuk menjawab permasalahan tersebut peneliti melakukan penelitian yang berjudul: Melatihkan Kemampuan Berpikir Kreatif dan Pemahaman Konsep dengan Pembelajaran Berbasis Inkuiri Terbimbing Pada Materi Interaksi Makhluk Hidup dengan Lingkungan.

\section{METODE PENELITIAN}

Penelitian ini merupakan penelitian pengembangan karena mengembangkan perangkat pembelajaran meliputi: RPP, Buku Ajar Siswa (BAS), Lembar Kegiatan Siswa (LKS), dan Penilaian berupa: Tes Berpikir Kreatif, Tes Pemahaman Konsep. Perangkat pembelajaran berbasis inkuiri terbimbing yang telah dikembangkan selanjutnya diujicobakan dalam pembelajaran IPA di kelas pada materi interaksi makhluk hidup dengan lingkungan. Penelitian ini dilaksanakan di SMP Negeri 1 Batumandi Kalimantan Selatan pada Semester Genap Tahun Pelajaran 2014/2015 diujicobakan pada 23 siswa di Kelas VII.

Penelitian ini dilakukan melalui dua tahap, yaitu tahap I merupakan pengembangan perangkat pembelajaran, sedangkan tahap II merupakan tahap uji coba. Perangkat dikembangkan dengan menggunakan model 4D dari Thiagarajan, et al., (1974). Proses pengembangan perangkat model ini terdiri atas empat tahap yaitu tahap pendefinisian, perancangan, pengembangan, dan penyebaran. Pengembangan perangkat yang dilakukan peneliti hanya sampai pada tahap ketiga karena diterapkan terbatas sehingga model 4D yang telah direduksi menjadi model 3-D yang dapat diperlihatkan pada Gambar 1.

Ujicoba perangkat dilakukan dengan menggunakan rancangan uji coba one group pretest-posttest design. Instrumen yang dikembangkan untuk mengumpulkan data dalam penelitian meliputi: 1) lembar validitas perangkat pembelajaran terdiri atas RPP, BAS, LKS, Instrumen Tes Berpikir Kreatif, dan Instrumen Tes Pemahaman Konsep; 2) lembar pengamatan keterlaksanaan pembelajaran; 3) tes kemampuan berpikir kreatif; 4) tes pemahaman konsep; 5) angket respon siswa. Pengumpulan data yang dilakukan dalam penelitian ini menggunakan teknik validasi perangkat pembelajaran, dokumentasi, observasi, pemberian tes, dan penyebaran angket.

Teknik analisis data dalam penelitian ini menggunakan deskriptif kuantitatif dan kualitatif. Validitasi perangkat pembelajaran reliabel jika koefisien reliabilitas $\geq 75 \%$. Keterlaksanaan rencana pembelajaran diukur melalui pengamatan oleh dua orang pengamat dan dinyatakan dalam bentuk skor ratarata. Kompetensi pemahaman konsep (aspek pengetahuan) siswa diukur menggunakan tes tulis di awal (pretest) dan di akhir (posttest) pembelajaran yang dianalisis secara deskriptif kualitatif menggunakan $\mathrm{N}$ -
Gain. Kompetensi keterampilan siswa dianalisis dengan menggunakan deskriptif kuantitatif. Tes kemampuan berpikir kreatif siswa diukur menggunakan tes tulis di awal (pretest) dan di akhir (posttest) pembelajaran yang dianalisis secara deskriptif kuantitatif dan dinyatakan dalam bentuk persentase. Respon siswa dinyatakan dalam bentuk persentase.

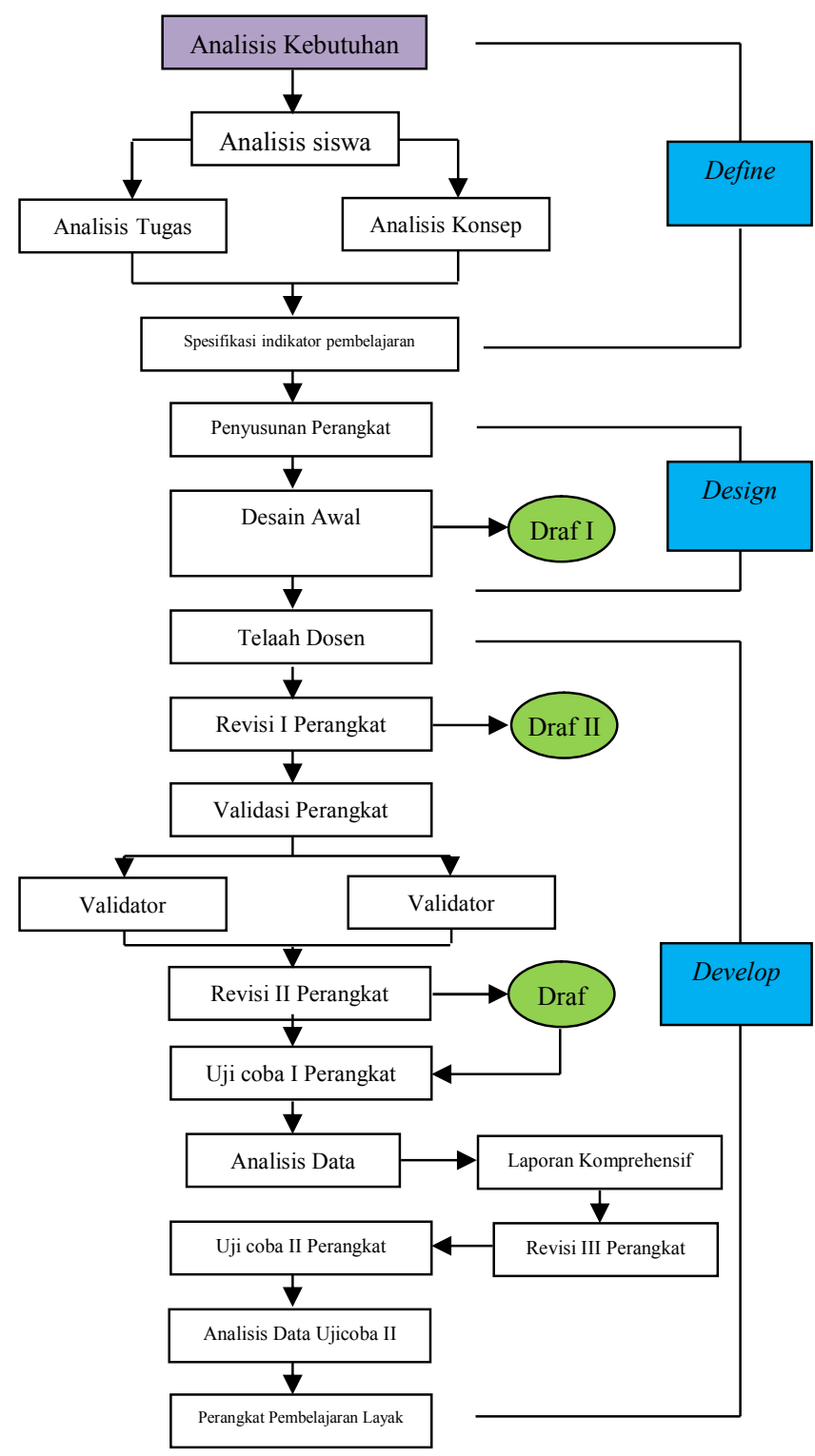

Gambar 1. Diagram Alur Tahap Pengembangan Perangkat Pembelajaran (diadaptasi dari Thiagarajan, et.al., 1974)

\section{HASIL PENELITIAN DAN DISKUSI}

A. Validitas Perangkat Pembelajaran

RPP berbasis inkuiri terbimbing yang dikembangkan pada materi interaksi makhluk hidup dengan lingkungan untuk melatihkan kemampuan berpikir kreatif siswa. Hasil validasi dari dua orang validator untuk aspek format adalah 3,50 dengan kategori valid, aspek isi sebesar 3,67 dengan kategori sangat valid dan rata-rata skor aspek bahasa adalah 3,67 termasuk kategori sangat valid. Instrumen lembar 
validasi RPP mempunyai rata-rata reliabilitas sebesar 91,20\% sehingga RPP dapat digunakan dan reliabel.

LKS yang telah dikembangkan oleh peneliti mencakup materi interaksi makhluk hidup dengan lingkungan. Hasil validasi dari dua orang validator untuk aspek format sebesar 3,63 dengan kategori sangat valid, rata-rata skor aspek isi 3,67 dengan kategori sangat valid, dan rata-rata skor aspek bahasa adalah 3,42 dengan kategori valid serta rata-rata reliabilitas instrumen lembar validasi LKS adalah 94,22\% sehingga LKS dapat digunakan dan reliabel.

BAS yang telah dikembangkan mencakup materi interaksi makhluk hidup dengan lingkungan meliputi: 1) komponen penyusun ekosistem; 2) saling ketergantungan; 3) pola interaksi makhluk hidup. Nilai rata-rata validasi dari dua orang validator untuk aspek isi adalah 3,40 dengan kategori valid, rata-rata skor aspek bahasa 3,50 dengan kategori valid, aspek penyajian memperoleh rata-rata skor 3,63 dengan kategori sangat valid, dan aspek fisik dengan rata-rata skor 3,83 dengan kategori sangat valid. Instrumen lembar validasi buku ajar mempunyai rata-rata reliabilitas 94,14\% sehingga BAS dapat digunakan dan reliabel.

Instrumen tes pemahaman konsep yang dikembangkan dalam penelitian ini berupa tes hasil belajar pada aspek pengetahuan yang terdiri dari 15 butir soal pilihan ganda dan 5 butir soal uraian. Validasi tes pemahaman konsep dan tes kemampuan berpikir kreatif siswa, memperoleh penilaian valid sehingga layak digunakan.

\section{B. Pengamatan Keterlaksanaan Pembelajaran}

Instrumen keterlaksanaan yang diamati meliputi: 1) pendahuluan memperoleh nilai rata-rata 3,83 dengan kategori baik; 2) kegiatan inti memperoleh nilai ratarata 3,87 berkategori baik; 3) penutup memperoleh nilai rata-rata 3,73 dengan kategori baik; 4) pengelolaan waktu memperoleh nilai rata-rata 3,67 ; dan 5) pengamatan suasana kelas memperoleh nilai rata-rata 3,83 sehingga sesuai dengan banyaknya antusias dari siswa dan guru.

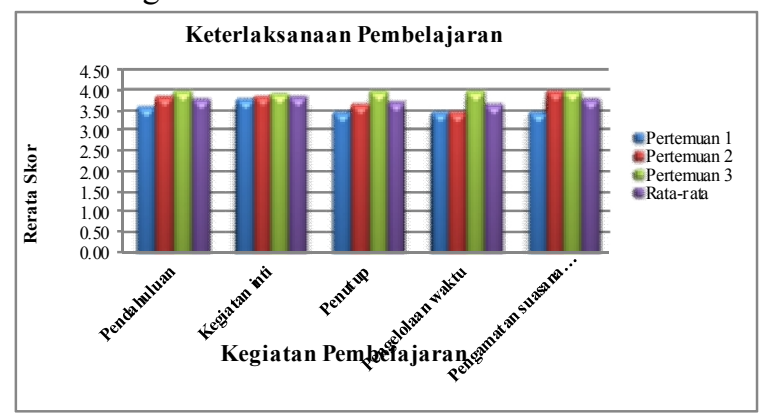

Gambar 2. Diagram keterlaksanaan Pembelajaran

Berdasarkan pengamatan yang dilakukan oleh dua orang pengamat, hasil keterlaksanaan pembelajaran menyatakan bahwa seluruh tahapan pembelajaran terlaksana dengan kategori tiap aspek baik, yaitu pada rentang skor 3.5-4.0.

\section{Hasil Belajar Pemahaman Konsep Siswa}

Hasil belajar pemahaman konsep siswa diukur dengan melakukan tes pemahaman konsep (aspek pengetahuan). Tes pemahaman konsep dilakukan sebanyak dua kali yaitu sebelum (Pre-test) dan sesudah pembelajaran (Post-test). Pre-test adalah tes yang diberikan sebelum pembelajaran dimulai dan bertujuan untuk mengetahui sampai dimana penguasaan dan pemahaman siswa terhadap materi pembelajaran yang akan diajarkan. Post-test adalah tes yang diberikan bertujuan untuk mengetahui hasil belajar akhir siswa setelah pembelajaran dilakukan. Tes hasil belajar pemahaman konsep siswa menggunakan soal tes pemahaman konsep yang terdiri atas 15 soal pilihan ganda dan 5 soal uraian. Soal tes pemahaman konsep disusun dengan memperhatikan tingkatan taksonomi revisi Bloom.

Berdasarkan hasil analisis dan deskripsi data pada Tabel 4.12 halaman 118, persentase ketuntasan siswa pada saat pre-test adalah $0 \%$ dan semua siswa tidak mencapai ketuntasan. Ketidaktuntasan siswa pada saat pre-test disebabkan oleh belum dilaksanakannya pembelajaran pada materi yang diujikan, sehingga siswa mengalami kesulitan ketika mengerjakan soal. Tes akhir (post-test) diberikan setelah dilakukannya pembelajaran dan didapatkan hasil post-test yaitu 100\% siswa mencapai ketuntasan. Seorang siswa dikatakan tuntas belajarnya (ketuntasan individual) jika nilainya telah mencapai $\geq 71$ (KKM SMPN 1 Batumandi) seperti yang ditunjukkan Gambar 2. Ketuntasan siswa ini tidak lepas dari keterlibatan aktif siswa selama proses pembelajaran.

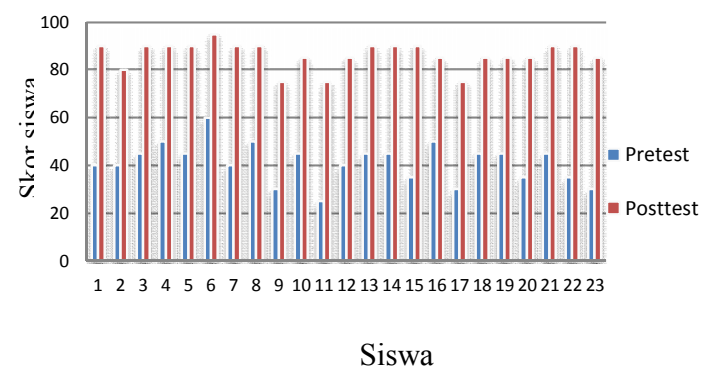

Gambar 3. Ketuntasan Individu pada Pretest dan Posttest Pemahaman Konsep

Peningkatan hasil belajar tes pemahaman konsep siswa pada ujicoba II diukur dengan menggunakan $\mathrm{N}$ Gain. Berdasarkan analisis data diketahui bahwa semua siswa mengalami peningkatan hasil belajar pemahaman konsep setelah dilakukan proses pembelajaran dengan $N$-Gain rata-rata adalah 0,77 dengan kategori tinggi (Wiyanto, 2008). Peningkatan yang ditunjukkan oleh 
hasil analisis dengan menggunakan $N$-Gain ini menunjukkan bahwa penerapan dari pengembangan perangkat pembelajaran IPA berbasis inkuiri terbimbing efektif dalam meningkatkan pemahaman konsep siswa pada aspek pengetahuan. Hasil ini didukung dengan hasil penelitian David (2006), Tangkas (2012), dan Anggraeni, dkk (2013) yang menyatakan bahwa pembelajaran dengan inkuiri terbimbing dapat meningkatkan pemahaman konsep siswa. Pembelajaran inkuiri terbimbing memberi kesempatan para siswa membangun pengetahuan dan membantu siswa mengembangkan pemahaman konsep (Lee, et al., 2010; Minner, et al., 2010; Pandey, et al., 2011; Tangkas, 2012; Anggraeni, et al., 2013). Pemahaman konsep siswa direpresentasikan oleh hasil tes belajar aspek pengetahuan atau dapat didefinisikan secara operasional sebagai skor yang diperoleh siswa setelah mengerjakan tes hasil belajar aspek pengetahuan yang telah dikembangkan oleh peneliti. Pemahaman konsep yang telah dicapai siswa merepresentasikan pencapaian kompetensi dasar yang telah ditetapkan sesuai materi interaksi makhluk hidup dengan lingkungan. Pencapaian Kompetensi Dasar (KD) menggambarkan hasil pemberdayaan siswa dalam membangun kemampuannya oleh fasilitas dan kondisi yang dibuat oleh guru.

Diketahui bahwa ketuntasan indikator pencapaian dan tujuan pembelajaran pada sebelum pembelajaran (pre-test) hanya mencapai rata-rata 41,30\%. Persentase ketuntasan indikator pencapaian dan tujuan pembelajaran meningkat hingga mencapai 86,30\% setelah pembelajaran dilaksanakan. Suatu indikator dikatakan tuntas apabila $\geq 80 \%$ siswa mencapai ketuntasan indikator, sehingga seluruh indikator dan tujuan pembelajaran dalam instrumen penilaian pemahaman konsep ini dapat dikatakan tuntas. Hasil perhitungan sensitivitas butir soal pemahaman konsep berkisar antara 0,30-0,65 dan diperoleh rata-rata sebesar 0,48. Sensitivitas butir soal digunakan untuk mengetahui apakah soal yang dikembangkan baik atau tidak, dapat dilihat dari tingkat sensitivitas tiap butir soal. Berdasarkan analisis hasil sensitivitas diperoleh bahwa semua soal yang dikembangkan mendapatkan nilai sensitivitas di atas 0,30 dan semua soal dinyatakan sensitif (Gronlund \& Linn, 1995). Hasil analisis tersebut menunjukkan bahwa butir soal pada pemahaman konsep memiliki kepekaan yang cukup terhadap efek pembelajaran yang diberikan. Hal ini menunjukkan bahwa peningkatan hasil belajar siswa setelah diberikan perlakuan merupakan efek dari perlakuan pembelajaran berbasis inkuiri terbimbing.

\section{Kemampuan Berpikir Kreatif Siswa}

Kemampuan berpikir kreatif siswa diperoleh melalui tes kemampuan berpikir kreatif berupa tes verbal yang terdiri atas lima sub tes dengan merujuk pada tes verbal yang telah dikembangkan oleh Munandar (1992) dan Rosidi (2013). Pemilihan tes verbal ini mengacu pada teori intelektual Guilford yang menyatakan bahwa berpikir kreatif atau disebut juga berpikir divergen merupakan kemampuan siswa dalam memberikan berbagai macam alternatif jawaban. Tes kemampuan berpikir kreatif siswa diberikan 2 (dua) kali yaitu pada saat sebelum pembelajaran (pre-test) dan sesudah pembelajaran (post-test). Lima sub tes yang disusun mewakili masing-masing indikator dari kemampuan berpikir kreatif yaitu kelancaran (fluency), keluwesan (flexibility), keaslian (originality) dan memerinci (elaboration). Tes verbal yang dikembangkan dalam penelitian ini dikaitkan dengan materi yang diajarkan yaitu interaksi makhluk hidup dengan lingkungan.

Sub tes yang diberikan dalam tes kemampuan berpikir kreatif merupakan bentuk tes verbal. Sub tes yang digunakan dalam penelitian ini terdiri atas 5 sub tes yaitu permulaan kata, menyusun kata, sifat-sifat yang sama, penggunaan luar biasa, dan apa akibatnya. Berdasarkan hasil analisis dan deskripsi tes kemampuan berpikir kreatif siswa yang dihitung berdasarkan jumlah jawaban siswa yang relevan kemudian dibuat penskoran. Indikator Fluency dihitung berdasarkan skor yang diperoleh siswa pada sub tes menyusun kata dan sifat yang sama. Indikator Flexibility dilihat dari skor siswa pada sub tes permulaan kata, dan indikator Originality dihitung berdasarkan skor siswa pada sub tes penggunaan luar biasa, serta indikator Elaboration dilihat dari skor siswa pada sub tes apa akibatnya.

Data dapat diketahui bahwa pemberian tes sebelum pembelajaran (pre-test) mendapatkan skor yang relatif rendah dilihat dari skor masing-masing indikator berpikir kreatif (Fluency, Flexibility, Originality, dan Elaboration) dengan persentase rata-rata $42,61 \%$ termasuk kategori cukup kreatif (Khanafiyah, 2010). Rendahnya capaian persentase pada saat pre-test tersebut disebabkan karena siswa belum pernah mengerjakan tipe tes seperti yang diujikan dan juga guru belum melaksanakan tahapan-tahapan pembelajaran berbasis inkuiri terbimbing yang dapat melatihkan berpikir kreatif. Hal ini memungkinkan mempengaruhi kemampuan siswa dalam mengerjakan tes ini. Persentase rata-rata tes kemampuan berpikir kreatif siswa setelah pembelajaran (post-test) dilihat dari skor masing-masing indikator berpikir kreatif (Fluency, Flexibility, Originality, dan Elaboration) yaitu sebesar $83,19 \%$ dengan kategori sangat kreatif (Khanafiyah, 2010). Data pada Tabel 4.10 juga dapat dilihat bahwa indikator fluency memperoleh skor yang relatif lebih tinggi dibandingkan dengan rata-rata skor pada indikator berpikir kreatif lainnya. Hal ini dapat dilihat dari rata-rata skor 2,52 menjadi 5,26. Tingginya 
rata-rata skor untuk indikator fluency tersebut karena sintaks atau tahapan pembelajaran inkuiri terbimbing lebih banyak melatihkan kemampuan kelancaran siswa dalam mengemukakan suatu gagasan atau ide seperti pada tahapan membuat hipotesis dan membuat kesimpulan. Faktor yang dapat menjadi penyebab lainya yaitu ada 2 (dua) sub tes yang mewakili indikator fluency yaitu sub tes menyusun kata dan sifat-sifat yang sama, sehingga mempengaruhi tingginya skor yang diperoleh. Indikator berpikir kreatif yang memperoleh skor yang relatif lebih kecil dari rata-rata skor indikator berpikir kreatif lainnya adalah Originality dan Elaboration. Skor siswa untuk indikator Originality dan Elaboration hanya sebagian kecil yang dapat memperoleh skor maksimal (3), sebagian besar siswa memperoleh skor 1-2. Perolehan skor yang kecil tersebut karena indikator Originality dan Elaboration termasuk kategori berpikir kreatif tingkat tinggi sehingga sebagian besar siswa mengalami kesulitan. Penyebab lainnya yaitu siswa terbiasa dengan pembelajaran konvensional yang hanya memberikan sedikit kesempatan kepada siswa untuk dapat mengemukakan banyak gagasan atau ide. Hasil tes berpikir kreatif siswa dapat dilihat pada Gambar 4 berikut.

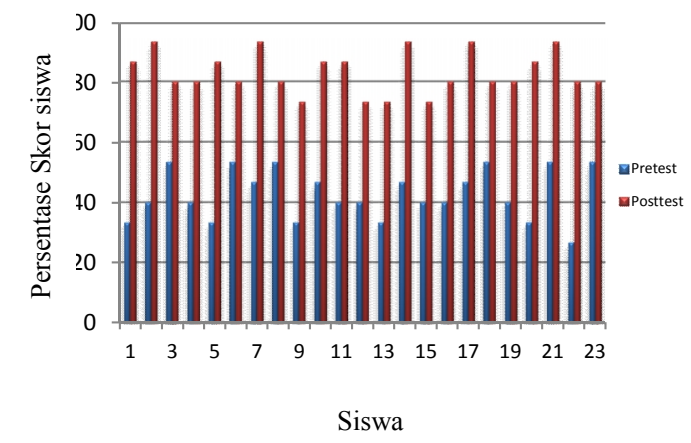

\section{Gambar 4. Hasil Tes Berpikir Kreatif}

Hasil ini menunjukkan bahwa siswa sudah dapat mengembangkan kemampuan berpikir kreatifnya. Hal ini diperkuat dengan adanya peningkatan kemampuan berpikir kreatif siswa yang ditunjukkan oleh nilai ratarata $N$-Gain sebesar 0,70 dengan kategori tinggi (Wiyanto, 2008). Peningkatan ini dapat diasumsikan bahwa peningkatan kemampuan berpikir kreatif siswa akibat dari pengembangan perangkat pembelajaran dan penerapan tahapan-tahapan pembelajaran berbasis inkuiri terbimbing yang dapat melatihkan indikatorindikator berpikir kreatif. Hal ini didukung respon yang diberikan oleh siswa terhadap perangkat pembelajaran inkuiri terbimbing yang dikembangkan dan implementasi perangkat dalam pembelajaran memiliki respon yang positif. Hasil ini menunjukkan bahwa pembelajaran inkuiri terbimbing dapat membantu siswa meningkatkan kemampuan berpikir kreatifnya. Hasil penelitian ini diperkuat oleh penelitian Utami (2014) dan Neka, dkk (2015) yang menyimpulkan bahwa pembelajaran inkuiri terbimbing dapat meningkatkan kemampuan berpikir kreatif siswa. Pembelajaran inkuiri mendorong siswa untuk terlibat aktif dalam mencari informasi sebanyak-banyaknya melalui pengamatan dan penyelidikan sehingga pembelajaran menjadi bermakna, guru hanya memberikan petunjuk-petunjuk seperlunya. Peserta didik yang terlibat aktif dalam pembelajaran dapat menunjukkan kreativitas untuk terus belajar menemukan hal-hal yang baru. Hal ini ditandai dengan kebebasan berpikir dan berimajinasi tanpa ikatan aturan berpikir konvensional.

Kemampuan berpikir kreatif atau berpikir divergen diartikan sebagai kemampuan menemukan banyaknya jawaban terhadap suatu masalah berdasarkan informasi yang tersedia dengan penekanan pada kuantitas, ketepatgunaan, dan keragaman jawaban (Munandar, 1992). Jawaban yang diberikan haruslah relevan dengan permasalahan yang ada, jadi tidak hanya semata-mata banyaknya jawaban yang dapat diberikan tetapi juga mutu dari jawaban yang diberikan tersebut harus ada relevansi jawaban dengan permasalahan yang diajukan. Makin banyak kemungkinan jawaban yang diberikan terhadap suatu masalah, maka makin kreatif seseorang. Menurut Supriadi (1996) mengemukakan bahwa orang kreatif memiliki ciri-ciri kepribadian kreatif yaitu memiliki imajinasi yang kuat, tertarik pada kegiatankegiatan yang kreatif, mempunyai rasa ingin tahu yang besar, memiliki rasa percaya diri dan mandiri, memiliki banyak inisiatif, tekun dan tidak bosan, senang mengajukan pertanyaan yang baik, memiliki gagasan yang original dan tidak kehabisan akal dalam memecahkan masalah.

\section{E. Respon Siswa}

Penelitian ini untuk mengetahui seberapa besar minat siswa terhadap perangkat pembelajaran IPA berbasis inkuiri terbimbing untuk melatihkan kemampuan berpikir kreatif siswa yang dikembangkan, maka dibuat angket respon siswa yang diberikan pada 23 siswa. Berdasarkan hasil analisis respon siswa terhadap pengembangan perangkat pembelajaran serta pelaksanaan pembelajaran didapatkan hasil rata-rata keseluruhan bahwa sebanyak 97,34\% siswa merespon dengan positif dan $2,66 \%$ siswa merespon kurang baik (Riduwan, 2010). Hal ini berarti siswa mendukung, merasa senang, dan berminat terhadap pembelajaran dengan menggunakan perangkat pembelajaran hasil pengembangan inkuiri terbimbing untuk melatihkan kemampuan berpikir kreatif dan pemahaman konsep. Hasil respon positif ini diperkuat dengan hasil penelitian dari Wulandari, dkk (2013) dan Utami (2014) yang menyatakan bahwa siswa merespon positif terhadap pelaksanaan pembelajaran inkuiri terbimbing yang telah dilakukan. 


\section{F. Temuan Selama Penelitian}

Temuan-temuan dalam penelitian ini adalah sebagai berikut:

1. Perangkat pembelajaran IPA berbasis inkuiri terbimbing untuk melatihkan kemampuan berpikir kreatif dan pemahaman konsep yang telah dikembangkan dinyatakan valid dan dapat digunakan dalam kegiatan pembelajaran IPA.

2. Kepraktisan perangkat pembelajaran IPA yang dikembangkan melalui implementasi pada ujicoba II dilihat dari keterlakasanaan RPP 1, RPP 2, dan RPP 3 dalam proses pembelajaran dengan rata-rata keseluruhan skor keterlaksanaannya berkategori baik, serta peningkatan aktivitas siswa pada ujicoba II mencerminkan tahap-tahap pada pembelajaran berbasis inkuiri terbimbing. Berdasarkan hasil di atas dapat disimpulkan bahwa perangkat pembelajaran IPA berbasis inkuri terbimbing yang telah dikembangkan praktis dilaksanakan dalam pembelajaran untuk melatihkan kemampuan berpikir kreatif dan pemahaman konsep.

3. Keefektifan perangkat pembelajaran melalui implementasi pada ujicoba II dilihat dari: hasil belajar kemampuan berpikir kreatif siswa, yaitu: rata-rata $N$-gain sebesar 0,70 dengan kategori tinggi; peningkatan pemahaman konsep dapat dilihat dari $N$-gain yaitu 0,77 dengan kategori tinggi; siswa merespon sangat positif hasil pengembangan perangkat dan pelaksanaan pembelajaran dengan inkuiri terbimbing. Hal tersebut dapat dilihat dari hasil analisis data respon siswa sebanyak 97,34\% siswa merespon dengan positif. Berdasarkan hasil di atas dapat disimpulkan bahwa perangkat pembelajaran IPA berbasis inkuri terbimbing yang telah dikembangkan efektif untuk melatihkan kemampuan berpikir kreatif dan pemahaman konsep.

\section{KESIMPULAN}

\section{A. Simpulan}

Berdasarkan hasil temuan dan diskusi hasil ujicoba

II, dapat disimpulkan bahwa perangkat pembelajaran berbasis inkuiri terbimbing yang telah dikembangkan valid, praktis, dan efektif untuk melatihkan kemampuan berpikir kreatif dan pemahaman konsep pada materi interaksi makhluk hidup dengan lingkungan.

B. Saran

1. Pengembangan perangkat pembelajaran berbasis inkuiri terbimbing dapat melatihkan kemampuan berpikir kreatif dan pemahaman konsep siswa sehingga perlu dikembangkan secara lebih luas pada materi pembelajaran IPA lainnya.

2. Guru harus dapat mengelola waktu selama pembelajaran agar pembelajaran bisa berjalan lebih efektif dan efisien.
3. Perlu penelitian pengembangan lebih lanjut terutama untuk melatihkan indikator berpikir kreatif Originality dan Elaboration.

\section{REFERENSI}

Anggraeni, N.W., Ristiati, N.P., dan Widiyanti, L.N.P.M. (2013). "Implementasi Strategi Pembelajaran Inkuiri Terhadap Kemampuan Berpikir Kritis dan Pemahaman Konsep IPA Siswa SMP”. Jurnal Pendidikan Sains Universitas Pendidikan Ganesha. Vol.3 Tahun 2013.

Arnyana, IBP. (2007). "Pengembangan Peta Pikiran untuk Peningkatan Kecakapan Berpikir Kreatif Siswa". Jurnal Pendidikan dan Pengajaran Undiksha, No.3 Tahun XXXX Juli 2007.

David, M. H. (2006). Instructor's Guide to ProcessOriented Guided-Inquiry Learning. SUNY: Stony Brook University.

Gronlund, N.T. (1995). Menyusun Tes Hasil Belajar. Diterjemahkan oleh Bistok Sirait. Semarang: IKIP Semarang Press.

Ibrahim, M. (2012). Konsep, Miskonsepsi dan Cara Pembelajarannya. Surabaya: Unesa University Press.

Kemendikbud. (2014a). Peraturan Menteri Pendidikan dan Kebudayaan No. 58 Tahun 2014 tentang Kurikulum 2013 Sekolah Menengah Pertama/ Madrasah Tsanawiyah. Jakarta: Kemendikbud.

(2014b). Peraturan Menteri Pendidikan dan Kebudayaan No. 103 Tahun 2014 tentang Pembelajaran pada Pendidikan Dasar dan Pendidikan Menengah. Jakarta: Kemendikbud.

(2014c). Peraturan Menteri Pendidikan dan Kebudayaan No. 104 Tahun 2014 tentang Penilaian Hasil Belajar oleh Pendidik Pada Pendidikan Dasar dan Pendidikan Menengah. Jakarta: Kemendikbud.

Khanafiyah, S \& Rusilowati, A. (2010). "Penerapan Pendekatan Modified Free Inquiry sebagai Upaya Meningkatkan Kreativitas Mahasiswa Calon Guru dalam Mengembangkan Jenis Eksperimen dan Pemahaman terhadap Materi Fisika. Jurnal Pendidikan FMIPA. Universitas Negeri Semarang.

Lee, H. Linn, M. Varma, K. and Liu, O. (2010). "How do Technology-Enhanced Inquiry Science Units Impact Classroom Learning”. Journal of research in science teaching. Vol.47 No.1, pp.71-90. 
Liliasari. (2000). "Model Pembelajaran untuk Meningkatkan Keterampilan Berpikir Konseptual Tingkat Tinggi Calon Guru IPA". Proseding Seminar Nasional 23 Pebruari 2000. (hlm. 135-140). Malang: Dirjen Dikti Depdiknas-JICA-IMSTEP.

Minner, D. Levy, A.and Century, J. (2010). "Inquiry Based Science Instructions-What is It and Does It Matter? Results From a Research Synthesis Years 1984 to 2002". Journal of Research in Science Teaching. Vol.47 No.2, pp. $474-496$.

Munandar, U. (2009). Pengembangan Kreativitas Anak Berbakat. Jakarta: Rineka Cipta.

National Research Council. (2000). Inquiry and The National Science Education Standards. Washington, DC: National Academy Press.

Neka, I.K., Marhaeni, A.A.I.N., dan Suastra, I.W. (2015). "Pengaruh Model Pembelajaran Inkuiri Terbimbing Berbasis Lingkungan Terhadap Keterampilan Berpikir Kreatif dan Penguasaan Konsep IPA Kelas V SD Gugus VIII Kecamatan Abang". Jurnal Pendidikan Sains Universitas Pendidikan Ganesha. Vol.5 Tahun 2015.

Riduwan. (2010). Skala Pengukuran Variabel-Variabel Penelitian. Bandung: Alfabeta.

72-94.

Rosidi, Irsad. (2013). Peningkatan Kemampuan Berpikir Kreatif Siswa Menggunakan Perangkan Pembelajaran Biologi dengan Pendekatan TASC (Thinking Actively In Social Context) (Tesis Magister Pendidikan Sains tidak dipublikasikan). Universitas Negeri Surabaya.

Supriadi, E. (1996). Kreativitas, Kebudayaan dan Perkembangan IPTEK. Bandung: CV Alfabeta.

Tangkas, I Made. (2012). Pengaruh Implementasi Model Pembelajaran Inkuiri Terbimbing
Terhadap Kemampuan Pemahaman Konsep dan Keterampilan Proses Sains Siswa Kelas $X$ SMAN 3 Amlapura. (Tesis Magister Program Studi Pendidikan Sains tidak dipublikasikan). Universitas Pendidikan Ganesha.

Thiagarajan, S. Semmel, Dorothy S, Semmel, Melvyn I . (1974). Instructional Development for Training Teachers of Exceptional Children. Washington, DC: National Center for Improvement Educational.

Undang-Undang Republik Indonesia Nomor 20 Tahun 2003 tentang Sistem Pendidikan Nasional. Jakarta.

Undang-Undang Republik Indonesia No. 14 Tahun 2005 tentang Guru dan Dosen. Jakarta.

Untari, M.F. (2013). Implementasi Pendekatan Saintifik (Scientific Approach) dalam Pembelajaran di Sekolah Dasar. Implementasi Pembelajaran Tematik dalam Pengoptimalan Kurikulum 2013 (pp. 1-6). Semarang: IKIP PGRI Semarang.

Utami, Arfiati U. (2014). Pengembangan Perangkat Pembelajaran IPA Model Inkuiri Dengan Tugas Proyek Untuk Melatihkan Kemampuan Berpikir Kreatif. (Tesis Magister Pendidikan Sains tidak dipublikasikan). Universitas Negeri Surabaya.

Wiyanto, (2008). Menyiapkan Guru Sains Mengembangkan Kompetensi Laboratorium. Semarang: Universitas Negeri Semarang Press.

Wulandari, Ade D., Kurnia, dan Sunarya, Y. (2013). "Pembelajaran Praktikum Berbasis Inkuiri Terbimbing Untuk Meningkatkan Keterampilan Berpikir Kritis Siswa SMA Pada Materi Laju Reaksi”. Jurnal Riset dan Praktik Pendidikan Kimia. Vol. 1 No. 1 Mei 2013. 